\title{
Research on the Online College English Teaching Mode from the Perspective of Autonomous Learning
}

\author{
Xiaoliang Cui*, Xiaoning Wang \\ Linfen College of Shanxi Normal University, China \\ *Corresponding author: Xiaoliang Cui, 515725284@qq.com
}

\begin{abstract}
In order to explore the online college English teaching mode from the perspective of autonomous learning and facilitate college students to better learn English independently as well as to master their English application skills, this article expounds the significance of online English teaching through theoretical analysis. At the same time, it expounds how to realize online English teaching in the perspective of autonomous learning, so as to improve the quality of English teaching and students' English skills.
\end{abstract}

Keywords: Autonomous learning; College English; Online teaching

Publication date: November 2021; Online publication: November 30, 2021

\section{Significance of online English teaching}

With the continuous development and progress of internet technology, the teaching modes in primary schools and even up to universities are constantly changing, and the teaching methods are gradually diversifying, especially the teaching quality in universities. With the development of internet technology, the transformation of teaching methods in universities is more obvious, and the online teaching mode has emerged at this historic moment. Nowadays, the hybrid mode of online and offline teaching is the most common; the traditional offline teaching mode is gradually being eliminated. The offline teaching mode embodies the cramming-style of teaching, and students are tired of dealing with the requirements of teaching tasks. In order to better realize the improvement of teaching quality, it is very important to make reasonable use of online teaching, especially in college English teaching. Online English teaching can stimulate students' interest in learning, and combined with autonomous learning, it can greatly improve students' English learning ability. Online teaching makes use of internet technology as well as various teaching tools and platforms to master students' learning ability and stimulate their autonomous learning potential. Big data and artificial intelligence can provide teachers with students' learning and data feedback comprehensively. The development of online English education is of great significance to promote English learning ${ }^{[1]}$.

\section{The online college English teaching mode from the perspective of autonomous learning}

\subsection{Making rational use of neo-constructivism to promote students' interest in autonomous learning}

Professor Zhuli Wang from the Teacher Development Center at Sun Yat-sen University has introduced the learning concept of "neo-constructivism," which conforms to the "network +" era. Neo-constructivism is an innovative achievement based on the learning concept of "constructivism," which is advocated by western scholars. Its background is exactly the two major challenges faced by learners - "information 
overload" and "knowledge fragmentation." The core idea of the western classical constructivism, advocated by Piaget and other scholars, can be epitomized by situation, cooperation, conversation, and meaning construction ${ }^{[2]}$. New constructivism covers a wide range of aspects. When the whole teaching process is integrated, it provides a theoretical basis for the whole teaching process, including the proposal of knowledge concept, the construction of a teaching knowledge system, the learning process of mastering knowledge, as well as the application and innovation of knowledge, which are all included in neoconstructivism. Neo-constructivism is able to solve teachers' doubts about teaching contents, improve the whole online teaching process, and explain the rationality of the online teaching mode. In the process of online teaching, teachers can fully and clearly display the teaching objectives, contents, and teaching requirements through PowerPoint slides as well as fully display the requirements of assessment standards in the form of tables, so that students can prepare themselves in the direction of the assessment standards [3]. In addition, teachers can also share relevant software and websites to students for their perusal, so as to provide more learning opportunities with diversified methods and ways to consult English materials as well as improve their mastery in English. Nowadays, in the era of fragmented knowledge learning, students can improve the construction of their knowledge system through online learning. At the same time, existing learning platforms and software can be utilized to retrospectively analyze the contents they have learned, so as to deepen the mastery of knowledge points and improve their English application ability through continuous innovation.

\subsection{Using internet technology and major platforms to provide a learning "center"}

With the continuous development of internet technology and major communication platforms, the rational use of internet technology and major platforms can promote students' autonomous learning, ensure the improvement of teaching quality, and achieve twice the results with half the effort ${ }^{[4]}$.

Online teaching is a very important form of English learning in colleges. Autonomous and spontaneous online learning can deepen students' mastery in English knowledge. At the same time, the online teaching mode can alleviate students' anxiety of speaking in class and provide support for the interaction between teachers and students as well as among students themselves. Online learning also provides opportunities to make better use of extracurricular teaching resources. Therefore, teachers can play the role of a guide to encourage students to use their spare time to engage in English learning activities, combine the content of classroom teaching knowledge, as well as test their ability to apply English knowledge. In the process of online teaching, teachers can design online English grammar competitions to improve students' understanding on standard writing, prepare English songs or stories as demonstration activities to help students improve their English innovation and application skills, as well as use the idea of schools as a protected environment to collect slogans and maxims through learning and other activities. Online learning can provide a platform for students to perform freely through a loose network environment. In this process, students can better master their English learning skills, speak enthusiastically, as well as display their mastery in English knowledge and grammar. Information technology platforms such as WeChat, QQ, DingTalk, and e-mails can also be used to interact with students, so as to enhance the communication between teachers and students, establish a harmonious relationship between them, and motivate students to learn English ${ }^{[5]}$. In online teaching, the goal of independent learning is integrated to encourage selfstudying, self-inspection, self-examination, etc. In this manner, teachers can gauge students' learning situations and existing problems, thus planning the next step in teaching. 


\subsection{Establishing collaborative groups in online English teaching to promote the interaction among students}

In the stage of college education, the interaction among students can effectively eliminate obstacles in their thoughts, behaviors, and emotions. The interaction among students can reduce learning anxiety and improve learning efficiency. Interactive communication can improve academic performance and promote personality development. Under the traditional teaching mode, students are instilled unilaterally by the teachers. They have poor learning enthusiasm, lack of self-confidence, and they do not dare to directly question the knowledge taught, resulting in personalization and innovation. The new educational model focuses more on making full use of the dominant position of students. Under the guidance of teachers, students can control their self-learning progress and learning methods, strengthen their interactions, as well as achieve development through mutual learning. The practical teaching environment of English majors in colleges and universities has adopted this innovative way of interaction among students. In addition, the effective teaching reform measures have been predicated on the actual teaching situation of the subject and the content of the teaching materials. In online teaching, students can be divided into groups for discussion and encouraged to engage in English dialogues. This would benefit students in a way of avoiding face-toface embarrassment ${ }^{[6]}$. Oral or formal dialogue, role play, and interactive forms of online oral English can promote students' learning enthusiasm and improve the efficiency of English teaching. In online English teaching, teachers can encourage students to interact. According to the content of the textbook, the type of online interaction can be selected, and internet technology can be used to design reasonable interactive courses or scenes. In online teaching, teachers would have to first put forward the main contents of the lesson, the contents to be mastered, and the questions that students should answer after autonomous learning. After actively answering the online questions, the students should be encouraged to provide their feedback on those questions, and finally, they should analyze and evaluate the contents of the learned knowledge. By forming small-scale interactive groups, students can interact and collaborate through discussion or role play, so as to develop their personalities, English application skills, and autonomous learning ability as well as improve the efficiency of online college English teaching.

\section{Conclusion}

In conclusion, in the process of online English teaching, English teachers should focus on guiding and encouraging students in the practice of autonomous learning, assist students and stimulate their interest in English learning, build on their courage to be able to express their skills, alleviate their anxiety pertaining to offline learning, as well as make full use of neo-constructivism, the internet, and major platforms to strengthen interaction between teachers and students as well as among students themselves.

\section{Funding}

This research was supported by the Linfen College, Shanxi Normal University, 2020 Foreign Language Education and Teaching Research Project of Vocational Colleges, Ministry of Education - Interactive Study on Online Teaching of "Comprehensive English" in Higher Vocational Colleges - Taking "Discussion Style Course" as an Example (Project Number: WYJZW-119).

\section{Disclosure statement}

The authors declare that there is no conflict of interest. 


\section{References}

[1] Zou Q, 2021, Application of Blended Teaching Mode in College English Reading and Writing Course. Journal of Xianyang Normal University, 36(04): 102-106.

[2] Yang T, 2021, Construction of College English Mixed Teaching Model Based on Deep Learning. Journal of Heihe University, 12(07): 93-94, 97.

[3] Jia W, 2021, Cultivation of College Students' Innovative Ability Based on Hybrid English Teaching Model. Teaching and Educating (Higher Education Forum), (21): 110-112.

[4] Wang H, 2021, Research on Hybrid Teaching Model for College English Based on "Online and Offline Teaching”. Journal of Heilongjiang Institute of Teacher Development, 40(07): 142-144.

[5] Duan H, 2021, Research on College English Teaching Methodology from the Perspective of "Internet +”. English on Campus, (28): 8-9.

[6] Wang J, Zhang X, Zhou XN, 2021, A Review of College English Online Teaching Research. Education Informatization Forum, (07): 45-46. 